Мирко В. Аћимовић

Филозофски факултет Универзитета у Новом Саду

mirla@open.telekom.rs
УДК 16 Петронијевић, Б.

Оригиналан научни рад

\title{
ЛОГИКА БРАНИСЛАВА ПЕТРОНИЈЕВИЋА ${ }^{1}$
}

Основама, структуром и теоријским домашајем формалне и метафизичке логике у филозофском систему Бранислава Петронијевића назначен је прелазак од науке о облицима мишљења и методама сазнања ка науци о начелима објективног логичког садржаја бића. Отуда су формална и метафизичка логика пропедеутичке науке Петронијевићевог система метафизике, која, заједно са теоријом сазнања и логиком, сачињава чисту филозофију у синтези свеопштег знања.

Кључне речи: формална логика, метафизичка логика, метафизика, биће, негација.

Напоредо са теоријом сазнања и психологијом, и логика је код Бранислава Петронијевића схваћена као пропедеутика за науку метафизике, па је и логика дакле једна приправна наука филозофије која се од других наука разликује по томе што једино она мисли форме чистог мишљења. Петронијевић је управо такву, формалну, логику потпуно одвојио од метафизике јер је ову науку схватио као науку о објективном логичком садржају, независном од питања колико се тај садржај слаже са објективним логичким садржајем у метафизичком смислу. Поближе, “Логика је наука о формама правилног и истинитог мишљења", или, другачије речено, “Логика је наука о формама мишљења и методама сазнања" (Петронијевић 1990:9). Овако схваћена, и на општим познатим основама традиционалне формалне логике, изведена логика битно одступа од његових, по његовом суду, дотадашњих оригиналних логичких

1 Овај рад рађен је у оквиру научно-истраживачког пројекта Историја српске филозофије, при Министарству за просвету и науку Републике Србије, Београд, одобреном 2011 године. 
испитивања у области метафизичке логике, започетих још дисертацијом о ставу разлога, настављених потом у разним поглављима у Принцииима метафизике, Основама теорије сазнања и Основама емпиријске психологије, те посебно у радовима о Хегелу, Аристотелу, математичкој индукцији, простој разлици, опозиционој супротности, геометријској методи границе и логичкој природи математичког доказа. Код Петронијевића не ради се ипак о развијеном систему метафизичке логике, нити о сасвим оригиналном теоријском постављењу формалне логике, засноване углавном на литератури тада владајућих логика Дробиша, Ибервега, Зигварта, Лоцеа, Вунта, Ердмана, Циена, Липса, Хилберта, Хефлера, Рабијеа, нешто мање Мила, Хамилтона, Џевонса, Мејерсона. ${ }^{2}$

О делима ових, и многих других, филозофа Петронијевић је у свом попису литературе оставио кратке али и језгровите назнаке, из којих је могуће претпоставити о њиховој битности за његов теоријски концепт формалне логике и опште методологије. Тако, за Ибервегов систем логике каже да опширно излаже формалну а накратко методолошку логику, али да је то дело битно са свог историјског увода и историјских примедби; Лоцеу, по свој прилици, приговара што формалну логику излаже на формалистичкој основи и што чисту логичку идеју ограничава на истините ставове и могуће појмове; изгледа да је добро код Зигварта што је изложио формалну и методолошку логику на бази реалне логике, али је сувише нагласио нормативни карактер формалне логике, па не одваја довољно логику од психологије, теорије сазнања и метафизике: ипак, то је једно од најважнијих дела логичке литературе; и Зигварт уноси сувише психологизма, али је и његово дело јединствено и неопходно, поготово због излагања метода појединих наука; Ердман је избегао психологизам, изложио је формалну логику на основама реалне логике; Џон Стјуарт Мил изложио је индуктивистичку номиналистичку логику, али не одваја логику од теорије сазнања и пати од психологизма; Кант је, по Петронијевићу, у логици на концептуалистичком становишту, а Хегел је типични представник реално-

2 Дела на која се Петронијевић наслања су, између осталих, Drobisch, M.W.: Neue Darstellung der Logik, 1836, Ueberweg, F.: System der Logik und Geschichte der logischen Lehren, 1857, Lotze, H.: Logik (System der Philosophie, 1, 1874), Sigwart, C.: Logik, 1873, Wundt, W.: Logik, 1880-83, Erdmann, B.: Logik, 1907, Ziehen, Th.: Lehrbuch der Logik, 1920, Lipps, Th.: Grundzüge der Logik, 1893, Hilbert, D. und W. Ackermann: Grundzüge der theoretischen Logik, 1928, Mill, J.S.: A System of Logic, 1843, Hamilton, W.: Lectures on Logic, 1859-61, Jevons, W.S.: Elementary Lessons in Logic, 1870. 
метафизичке логике.

Из приложене литературе видљиво је како су Петронијевићу била позната и дела с подручја логике која нису била од изворног значаја за његову рецепцију формалне логике, тако се наводи Хусерлово дело Logische Untersuchungen (I 1900, II 1901), за које се каже да се бави фундаментима логике и да садржи оштроумну и умногоме оправдану критику психологизма, те да је Хусерл типични представник чисте логике (Петронијевић 1990:20). Затим, наведена су и значајнија дела математичке логике код Була, Моргана, Вена, Вајтхеда, Расла, Пеана, Кутире, која и представљају систематска заснивања и излагања ове науке, а која нису битно утицала на теоријско постављење предметног подручја формалне логике, како је то проведено код Петронијевића, стога и не стоје никакви Петронијевићеви коментари о њима.

У поближем одређењу, какоје то речено у Предговору, књигајепроизашла из предавања, годинама држаних на Великој школи и Универзитету, “а делимице и из самосталних логичких испитивања његових публикованих у његовој докторској дисертацији и доцнијим филозофским делима" (Петронијевић 1990:5). ${ }^{3}$ Одступања од традиционалне формалне логике посебно су приметна у теорији суда, а тамо где нема одступања, Петронијевић се понајвише ослањао на тада позната дела Ердмана (Erdmann, Logik, Bd. I, Logische Elementarlehre, 1923), Хефлера (Höfler, Logik, 1922) и Рабијеа (Rabier, Leçons de Philosophie, t. II, Logique, 1917), чији је извод приредио на српски језик Милан Шевић. Петронијевић је напоменуо и то да је Милан Шевић приредио изводе и из колективног дела De la Méthode dans les Sciences (у Педагогијској књижници), а да је пре тога Алимпије Васиљевић дао кратак извод на српском језику из Миловог система логике.

Шта заправо Петронијевић мисли под логиком речено је у уводном делу, где се накратко излажу најпре дефиниција логике, онда однос логике према

3 Петронијевић је предавао логику најпре на Великој школи а онда и на Универзитету у Београду, на свим студијским групама Филозофског факултета, и то све до свог пензионисања 1927. године. Свој уџбеник Основи логике објавио је тек 1932. године, и то је први универзитетски уџбеник логике, пре тога на Великој школи логику су према својим уџбеницима предавали Константин Бранковић, Милан Кујунџић и Алимпије Васиљевић. О томе, између осталог, Аћимовић, М.: "Неокантовска логика Константина Бранковића", Традиција наставе филозофије, IV, Пропаидеиа, Едиција часописа Архе, Нови Сад, 2010; Аћимовић, М.: “Теоријска филозофија Михаила Христифора Ристића”. Филозофски годишњак, Бања Лука, 7/2009. 
психологији и теорији сазнања, а затим се расправља о томе да ли је логика принципска или нормативна наука, те које су основне поставке главнијих праваца логике у њеној историји. Речено је већ, како је логика код Петронијевића схваћена као наука о формама правилног и истинитог мишљења, или, као наука о формама мишљења и методама сазнања, при чему је мишљење схваћено као субјективна психичка функција у којој свесни субјект представља, или замишља, садржаје који или стварно постоје или за које се претпоставља да би могли да стварно постоје или који постоје само као замишљени: тај замишљени садржај назива се логички садржај мишљења. Мишљење је притом правилно и истинито, правилно је онда када је изведено у формама и када одговара законима који условљавају егзистенцију логичког садржаја, а истинито је онда када један замишљени садржај или стварно постоји или би могао да постоји или када је правилно замишљен: управо је овако схваћено истинито мишљење заправо сазнање, које је утврђивање стварне и идеалне датости замишљеног садржаја. Логика је отуда наука о логичком мишљељу, наука о мишљењу у коме се субјективно замишља објективни логички садржај, стога се она бави и правилним и истинитим мишљењем, будући да је истинито мишљење циљ правилног мишљења (Петронијевић 1990:9-10).

Управо по овоме логичком садржају логика се и разликује од психологије, јер је за психологију мишљење психичка функција која се састоји из мислених представа. Разликује се логика и од теорије сазнања, која је пак код Петронијевића “фундаментална филозофска дисциплина”, чији је задатак да испита могућност сазнања, како филозофског (логике и метафизике), тако и научног и практичког: при томе, нити теорија сазнања претпоставља логику, нити логика претпоставља теорију сазнања, будући да логички закони важе универзално а закони теорије сазнања су партикуларни. Према томе, теорија сазнања у својим рефлексијама о логичким формама и законима не претпоставља њихову универзалну важност (Петронијевић 1990:12-13).

С тог становишта, логика је најпре теоријска, принципска наука, а затим је и нормативна, практичка наука, и не своди се на вештину мишљења, она наиме не може да омогући стваралачко мишљење код оних који за то немају природних основа, али може да појача способност логичког мишљеља. А по питању о томе на који начин постоје логички садржаји мишљења Петронијевић је разлучио 
основне правце логике, дакле формалистичку, реалну, концептуалистичку, номиналистичко-индуктивну и формално-методолошку логику. Математичка или симболичка логика сврстана је у споредни правац формалистичке логике, као и еволуционистичка, биолошка и психологистичка логика унутар номиналистичко-индуктивне логике. Овим логикама Петронијевић је понешто приговорио. Формалистичка логика (Болцано, Хербарт, Лоце, Хусерл) тврди да постоји чиста логичка идеја, а то постојање није могуће јер не може да нешто стварно не постоји а да притом није ништа. Ни у реалној логици, како је то код Аристотела или Хегела например, није решен проблем логичког садржаја, јер је објективна стварност као основа логичког садржаја поистовећена са логичком идејом, као да лежи у њеној основи: ако се одбаци ова идеја о идентичности објективне стварности са логичком идејом, онда се може прихватити принцип реалне логике о општости и нужности логичких форми и закона који важе за стварност, што напослетку и произилази из законитости природе и математике која се на њу и примењује. Ни концептуалистичка, ни затим номиналистичка логика није решила тај проблем, али је правац формално-методолошке логике (Џевонс, Зигварт, Вунт и Ердман) на том трагу, премда то није и конзеквентно изведено у појединостима. Зато, каже Петронијевић, “и ова књига одговара томе правцу” (Петронијевић 1990:17).

У Резимеу Петронијевић је навео формалистичку, реалистичку или метафизичку, концептуалистичку, номиналистичку, и индуктивну, и реалну или научну логику, с обзиром на начин постојања логичке идеје, и притом је напоменуо како је прихватио реалистичку или метафизичку и реалну или научну логику, допуњујући их темељном разликом између објективне и субјективне логике, јер се логички садржај субјективног мишљења не подудара сасвим са објективном логичком идејом (Петронијевић 1997:118). Примера ради, за субјективну логику постојање је предикат, премда је објективно оно само чиста позиција суштине.

Овако схваћену логику Петронијевић је поделио на формалну логику и општу методологију, формалну логику је затим предочио учењима о појму и категоријама, о теоријама суда и законима мишљења и о закључивању и силогистичким фигурама, а општу методологију размотрио је преко учења о методама готовог сазнања и методама сазнања у постајању. То је дакако опште 
прихваћени сценариј формалне логике у њеном теоријском и практичком смислу, и у томе се Петронијевићев нацрт система логичке науке битно не разликује. И код Петронијевића је, сасвим разумљиво, формална логика одређена као “део Логике који се бави формама и законима логичког мишљења”, при чему се под формама мишљења подразумевају појам, суд и закључак, у ужем смислу, у ширем смислу овима се придружују категорије, закони мишљења и силогистичке фигуре; надаље, под законима мишљења у ширем смислу подразумевају се категорије и силогистичке фигуре, док у ужем смислу мисли се на законе мишљења који су заправо најопштији судови.

На основу овога и сачињена је расподела грађе логике, и то је оно што је упитно, наиме, категорије су издвојене од појмова као закони мишљења, а фигуре силогизма, издвојене од посредног дедуктивног закључивања, интерпретирају се као закони мишљења. Јер, Петронијевић говори у првом одељку првог дела “О појму и категоријама”, други одељак првог дела насловио је “Теорије суда и закони мишљења" а у трећем одељку говори се “О закључивању уопште и о силогистичким фигурама”. Оваква Петронијевићева интервенција сасвим сигурно нема неког озбиљнијег теоријског покрића у традиционалној формалној логици, поготово не у битним системима формалне логике у историји ове науке.

Како је већ предочено, Петронијевић је озбиљније приговорио оним системима логике у којима је очит психологизам. Својим концептом логичке науке одредио се и према психологији, којој је предмет мишљење као психички процес, састављен из мислених представа. Али, управо је на овом трагу одредио појам појма, рекавши како формално-логичка дефиниција појма гласи: “појам је замисао онога што је опште у множини појединачних престава одн. престављених објеката исте врсте” (Петронијевић 1990:30). У овој кантовски постављеној дефиницији појма у основи стоји појам представе, чија општост појединачних својстава сачињава заправо представу представа̂, а то код Петронијевића није само психички супстрат појма и психичка генеза појма, него сам појам појма. Слике имагинације представљају психички супстрат појма, отуда чињеница да појмови имају своје порекло у представама и преко њих у опажајима, отуда дакле психолошка генеза појма, из које се онда мисаоним процесима анализе, синтезе, апстракције, генерализације, детерминације, стварају логички појмови, који се, пак од психолошких појмова разликују по 
томе што се односе и на безграничан број представа, стога су логички појмови опште представе а психолошки појмови колективне представе, или множина представа везаних за једну реч.

Наравно, задатак је формалне логике да испита готове логичке појмове, њу не занима психолошка генеза појма, али, као што је већ показано, код Петронијевића психолошка генеза појма стоји у основи логичких појмова будући да је појам појма садржан у општости представе, а то значи како у појму појма није прекорачен психички супстрат појма, представа. Овај остатак психологизма код Петронијевића није превладан, премда се инсистира на разлици између психолошког и логичког одређења мишљења и свих његових облика и процеса, што је очито и у даљњим одређењима садржаја и обима појма, њихових врста и њихових међусобних односа. У Резимеу Петронијевић је себи приписао заслугу што је, разматрајући однос између садржаја и обима појма, под којима је подразумевао скуп свих ознака појма и множину нижих појмова, допустио постојање појединачних појмова поред општих појмова, али сматра непојмљивим постојање појединачних објеката у субјективној логици (Петронијевић 1997:118). Такође, релативне појмове сматра само нарочитим случајем корелативног појма, а са гледишта субјективне логике он, опет, допушта само шест категорија, дакле ствар, квалитет, квантитет, стање, ред и однос (Петронијевић 1990:46, Петронијевић 1997:118). О њима је расправљао најпре у Principien der Metaphysik (1, II), где је изостала категорија ствари. Тиме је Петронијевић показао како није прихватио табеле категорија како су их “набрајали” Аристотел, Кант и Зигварт. Осим тога, Петронијевић је скратио и табелу врста и односа међу појмовима, у врсте је навео апстрактне и конкретне, колективне и неколективне, корелативне и некорелативне и релативне и апсолутне појмове, док је у односе међу појмовима уврстио идентитет, једнакост, сличност, различност, супротност и диспаратност. У разјашњењима ових врста и односа појмова Петронијевић се послужио и графичким представљањем, и та разјашњења не одступају битно од традиционалних гледања у формалној логици.

То исто важи и за излагање о теоријама суда, из којих је видљиво како је потпуно одбацио Хамилтонову, Брентанову, Лоцеову и Аристотелову логичку теорију суда, а да је прихватио теорију иманенције предиката у субјекту, која 
се огледа у потпуном или делимичном идентитету предиката са субјектом. Дакле, Петронијевић није стајао на позицијама теорија супсумције по обиму, идентитета по обиму, идентитета по садржају и егзистенцијалне теорије суда, a да је са извесним допунама прихватио теорију иманенције предиката у субјекту: та се допуна односи на дефиницију суда, наиме прост логички суд је трочлани спој појмова где копула изражава делимични или тотални идентитет субјекта са предикатом. Занимљиво, Петронијевић је у напомени ставио како је Љубомир Недић написао једну темељну студију о Хамилтоновој теорији суда, објављену 1886 код Вунта, у Philosophische Studien, Bd. III, и то је, с претходним напоменама о Милану Шевићу и Алимпију Васиљевићу у литератури, датој у изводима, једино што је овде речено о српској филозофији. А што се тиче поделе судова, Петронијевић је мишљења да су сви прости судови истовремено категорички и аподиктички, док су проблематички и асерторички само психолошки судови, као што су и Кантови аналитички и синтетички судови, а прости судови су по квалитету, квантитету и садржају распоређени на потврдне и одричне, онда на сингуларне, партикуларне и универзалне, те потом на егзистенцијалне, есенцијалне и релационе судове. Овим судовима одговарају закони мишљења, па Петронијевић, као и Лоце, признаје законе идентитета, противречности, искључења трећег и довољног разлога, будући да одговарају, редом, потврдном, негативном, дисјунктивном и хипотетичком суду. А закони мишљења су одређени као услови које један логички суд мора да испуни да би био истинит, стога су закони мишљења најопштији судови.

Продужено суђење на које је примењен став разлога код Петронијевића је закључивање, односно, то је извођење једног суда из једног или више судова, па је стога закључивање непосредно (субалтернација, опозиција, конверзија, еквиполенција и контрапозиција) и посредно, које је овде представљено углавном као силогизам (категорички, хипотетички и дисјунктивни, онда полисилогизам, просилогизам, еписилогизам, ентимем, епихерм соритес).

Овим је завршена теоријска садржина формалне логике, схваћене као наука о чистим формама мишљења, асптрахованим од садржине; методолошка логика, или методологија, занима се мишљењем као сазнањем, дакле “мишљењем испуњеним садржајем”, њу занимају начини, или методе, испуњења садржајем, којима се сазнају стварни и замишљени објекти (Петронијевић 1990:129). 
Општа методологија излаже опште методе свег научног сазнања а специјална методологија излаже методе појединих наука, стога је она прва заправо “наука наука".

У тој општој “науци науке” методе су, сходно ступњевима сазнања, дескриптивне и експликативне а онда и методе готовог сазнања и методе сазнања у постојању. У дескриптивне методе увршћене су анализа, посматрање, експеримент, дефиниција и класификација, у експликативне методе спадају синтеза, индукција, дедукција, аналогија, хипотеза и доказ; а, опет, у методе сазнања у постојању су анализа, синтеза, посматрање, експериментисање, индукција, дедукција, аналогија и хипотеза, док у методе готовог сазнања сврстене су методе дефиниција, класификација и доказ. Оваква подела је и по Петронијевићу мање више релативна, и то он показује у опширнијим разјашњењима и примерима из различитих природних наука, поготово из биологије, космологије и геометрије, па је овај део излагања методолошке логике један резиме логичких основа природних наука, дакле логички основ једне својеврсне филозофије природе.

Два појма из природних наука свраћају Петронијевићу посебну пажњу, узрок и закон. Узрок је схваћен као онај феномен за којим не само да стално и безусловно следује последица, већ и који, производећи последицу, преноси своју енергију на њу (Петронијевић 1990:194). Енергија је способност за рад, рад је савлађивање отпора насупрот једној сили, мера рада се састоји у производу из силе и пређеног пута. Према постулатима природњачког каузалитета, свака промена има свој узрок у другој промени, која јој претходи, свака је промена просторно и временски сложена. Али, узрок је само она промена која своју енергију преноси на последицу.

С тим је увези и појам закона, закон је наиме став у коме је изражена стална веза између двеју чињеница, а чињенице су или истовремене или сукцесивне, што се изражава законима коегзистенције или секвенције (сукцесије), а осим тога закони су још феноменални и каузални, дескриптивни и експликативни, квалитативни и квантитативни, емпиријски и рационални, апроксимативни и прецизни, нормални и гранични и индивидуални и колективни.

У разјашњењу логичког проблема индукције, Петронијевић се позива на своје решење овог проблема, а по њему, математичка индукција се састоји 
из бескрајног низа хипотетичких силогизама, састављених из партикуларних премиса. Тиме се Петронијевић разликује од оних решења по којима се математичка индукција своди на један једини хипотетичко-категорички силогизам (Мијо, Гобло, Расл, Џонсон), или по којима се она састоји из бескрајног низа хипотетичких силогизама, у којима се понавља једна те иста хипотетичка премиса (Поенкаре). Поставља се и питање о вези индукције, посебно каузалне, и логичке природе става узрочности, и ту је Петронијевић усвојио теорију по којој је став узрочности постулат а каузална индукција силогизам чија је прва премиса тај став, а то надаље значи да нису истините теорије Канта, Апелта, Хјума и Џона Стјуарта Мила. Из овога следи да логички треба разликовати детерминизам природе од њене узрочности, тако да став узрочности потпада под став детерминизма.

О дедукцији, аналитичкој и синтетичкој, Петронијевић говори са становишта примера из математике и физике, о овој првој из примене општег биномног обрасца, а о овој другој из Еуклидове геомерије, Кеплеровог трећег закона планетарних кретања, Хајгенсове формуле убрзања при централном кретању и Њутновог закона гравитације. Тако, Петронијевић примерима из природних наука настоји да прикаже значај дедукције у овим наукама, а тај је значај трострук, наиме, он служи као верификација хипотетички датих чињеница и закона, служи затим за објашњење чињеница и закона откривених индукцијом и омогућује напослетку откриће нових чињеница и закона. У том је смислу дедуктивни закључак потпуно сигуран, индуктивни је вероватан а закључак по аналогији је више мање несигуран (Петронијевић 1990:227).

С тим је у вези и излагање о хипотезама, схваћене и као претпоставка и као метода чињеница и закона, а о томе се Петронијевић позива на примере из историје природних наука, на Њутна, Птолемеја, Коперника, Галилеја, Дарвина, Ајнштајна, на које се позива и онда када излаже односе између хипотеза и теорија, при чему теорије садрже проверене и доказане хипотезе, или су на њима засноване. Основна хипотеза на којој почива једна теорија за Петронијевића је централна хипотеза, или принции теорије. Теорије су дескриптивне и експликативне, сходно овим ступњевима сазнања, а на темељу овога и може се говорити о једном довршеном систему сазнања.

Такав један довршени систем сазнања је заправо савршени систем неке 
науке, уколико се под системом подразумева уређено сазнање засновано на евидентним принципима, а који је притом логички правилан уколико је строг и природан (Петронијевић 1990:244). А да би уопште био могућ савршени систем занован на евидентним принципима, он мора да испуни услове: у њему би најпре дефиниције морале да буду адекватне, затим први недоказани ставови морали би бити аксиоматски, доказивање би морало бити дедуктивно-синтетички, а само тамо где то није могуће допуштени су и индиректни и аналитички докази, и напослетку, експликација би се морала потпуно поклапати са демонстрацијом.

Управо оваквим условима не одговарају ни, до сада, најсавршенији покушаји геометријских и аритметичких система, какви су код Еуклида, Хилберта и Пеана. Ни покушаји заснивања дефинитивних система у логици (Бул) или у метафизици (Спиноза, Хегел) нису од успеха, Спиноза имитира Еуклидов геометријски систем а Хегел изводи категорије на основу дијалектичке методе противречности. У емпиријским наукама нису још могући дефинитивни системи зато што је експликација искуствених чињеница увек релативна, што је експликација непотпуна, али, премда је експликација овде релативна и непотпуна, она је у емпиријским наукама нужна.

Али, ако је уопште и могућа, апсолутна и потпуна експликација појава искуствене стварности биће могућа само у једном дефинитивном систему људског знања у коме ће метафизика, изведена као строг дедуктивно-синтетички систем, имати централни положај, а такав један систем тоталног људског знања биће можда могућ тек после неколико хиљада година непрекидног интелектуалног прогреса људског рода (Петронијевић 1990:253). Петронијевић је међутим у Резимеу о овоме рекао нешто другачије, наиме, након што су се одвојено кретале током хиљада година, метафизика и емпиријске науке можда ће остварити јединство у систему потпуног знања (Петронијевић 1997:121). Дакле, или ће тек након хиљада година доћи до овога јединства, или је после већ протеклих хиљада година можда могуће остварење јединства метафизике и емпиријске науке у систему потпуног људског знања. Петронијевић је, да потсетимо, у свом говору на Академији наука рекао ја сам постао научник да бих и надаље могао бити метафизичар, то отуда да би се отклонили конфликти који би могли настати између мога метафизичког система $и$ емпиричке стварности, односно да се и са емпиричке стране тај систем допуни и потврди. 
Изгледа дакле да је Петронијевићев систем метафизике, и њеног саглашавања са емпиријским наукама, један од одговора на могућност остварења уједињења метафизике и емпиријских наука у систему потпуног људског знања. Стога ове завршне сцене основа логике битно доприносе на сагледавању теоријских разлога заснивања Петронијевићевог метафизичког система као синтезе свег знања, па и на процени онога што је о томе и он сам мислио, мислећи притом и свој властити допринос таквој синтези. А то што је мислио, рекао је још једном, у напомени у Основама логике, наиме, “и писац ове књиге покушао је у својим Принципима метафизике да поред аналитичко-емпиричког даิ и један дедуктивно-синтетичан систем Метафизике... на основу дијалектичке методе супротности".

И, доиста, остало је ово на покушају, на великом, у српској филозофији, и једином покушају.

У Основама логике, које је и по Петронијевићевом мишљењу из Резимеа “главно логичко дело аутора”, приказан је дакле формални систем логичке науке, у којем међутим стоје напомене о његовим пређашњим радовима с подручја метафизичке логике. Те две логике сасвим су јасно раздвојене у Предговору Основа логике, где је речено како логику у формалном смислу треба схватити као науку о субјективном логичком садржају потпуно независно од питања, колико се тај садржај слаже са објективним логичким садржајем у метафизичком смислу. Исто тако, његова су се "ранија оригинална логичка испитивања кретала поглавито у области метафизичке Логике”, стога је морао одлучити да буде "што је могуће мање оригиналним и да се ослони што је могуће више на традиционалну формалну Логику”, премда и у томе има и знатних одступања.

По тим његовим напоменама, своја је критичка испитивања с подручја формалне логике и методологије Петронијевић приредио у Основама теорије сазнағ $а$, затим у студијама о Хегелу и Хартману, Аристотелу, Кантору, Дарвину, Мендељејеву, Њутну, у Основама емпиријске психологије, Историји новије филозофије, Универзалној еволуцији... Та испитивања тичу се критике основних претпоставки формалистичке логике, односа форме и материје, прелажења идеје у природу, критике психолошких теорија о мишљењу, Лајбницових решења проблема индивидуације, Хамилтонове теорије суда, става идентитета, става 
разлога, класификације, Канторовог доказа о реализацији најмањег бесконачног броја (чланак у Annalen der Naturphilosophie, Bd. X, 1911, S. 359), затим тичу се и критике наивног реализма, закона асоцијације, закључивања математичком индукцијом, Хјумове емпиристичке теорије каузалитета, нужности става узрочности, закона корелације и некорелативног развитка, двоструке артикулације доње вилице код најпримитивнијих сисара и сисарских рептила, централне магме, космолошких хипотеза, аналогије одабирања, берлинског егземплара... Премда су неки од ових проблема формалне и методолошке логике истовремено и проблеми метафизичке логике, то метафизичко преиспитивање тих проблема проведено је поглавито у Принципима метафизике, онда докторској тези о ставу разлога и у Универзалној еволуцији, делом и у Основама теорије сазнаља. Судећи само по напоменама у основама логике, метафизички проблеми логике, како су испитани у споменутим студијама, односе се на решења питања индивидуације, решења табеле метафизичко-логичких категорија, проблема промене, става разлога, класификације подударањем, необоривих разлога, универзалној еволуцији...

Наравно, нацрт једне могуће метафизичке логике код Петронијевића далеко прекорачује проблемски склоп овде назначених ствари логике, и он је већ започет дисертацијом о ставу разлога а проведен превасходно у расправама о принципима метафизике и, делом, у универзалној еволуцији, која је, заправо, једини нацрт филозофије природе, уместо неизведене филозофије природе из Принципа метафизике.

Петронијевићева докторска теза о логичком истраживању става разлога, својим општим и посебним делом, ставља у разматрање главно питање, како он каже и у Резимеу, наиме, да ли је највиши принцип свести аналитичка или синтетичка истина, и онда, шта доиста јесте принцип довољног разлога, те какав је његов однос према начелима сврхе, еволуције и супстанције. Стога се најпре испитују опште одредбе става разлога, априоризам и емпиризам, суштина суда, аналитички и синтетички судови, ставови идентитета и противречности, а онда се посебном одредбом става разлога као општег закона мишљења разматрају 
реални и сазнајни разлог, негација, разлог и последица, начело релације, кретање и мировање, саморазлог, нужност, узрочност, зависност, начела квалитативне и квантитативне еквиваленције.

У општој одредби става разлога полази се најпре од уверења како све оно што јесте садржај мишљења мора се повиновати његовим општим темељним законима, а суштина мишљења састоји се у рашчлањивању свих садржаја мисли на многоодносно јединствено мноштво, будући да је свако мишљење односно мишљеље, дакле мишљење које поставља односе међу својим садржајима мисли (Petronievics 1898: 4). Став разлога изражава управо ту суштину мишљења, наиме, да је однос суштина мишљења, те да се ништа не може замислити без односа према чему другом, а то и јесте нужна синтеза садржаја мисли, у којој није од значаја шта него да јесте неки однос. А, опет, пошто је мишљење у суштини суђење, питање је, да ли у мишљењу постоје синтетички судови a priori, или су сви априорни судови аналитички, заправо, овде стоје три питања, да ли уопште и постоје априорни судови, даље, шта је суд и шта су то аналитички и синтетички судови. Овде је дакле реч о и томе да ли је уопште оправдано Кантово разликовање аналитичких и синтетичких судова, и Петронијевићев је одговор да такво разликовање има индиректан значај само уколико постоје прости судови са два и више субјекта, те се тиме показују као синтетички судови. Априорни судови доиста постоје, а сам суд је разјашњен Петронијевићевом синтетичком теоријом предикације и егзистенције, или сједињеним гледиштем субјективне и објективне логике, у којој су издвојени релациони судови.

У том је дакле смислу суђење и схваћено као повезивање појмова, који су елементи мишљења, јер појмови као такви постоје само у судовима. Отуда је суштина психичке функције мишљења схваћена као констатовање датога у његовој унутрашњој структури, у његовој таквости, тако да мишљење мора да раздвоји оно што хоће да констатује од онога на чему треба да констатује, како би се уопште и изрекла иманенција одређености предиката у субјекту (Petronievics 1898:5). То се раздвајање догађа у мишљењу, али суд се не састоји у раздвајању онога што је претходно састављено нити у састављању претходно растављеног, него суд раздваја заједнобивствујуће како би управо утврдио заједност датога. Отуда три класе судова, егзистенцијални, есенцијални и релациони судови, 
где се ови последњи од претходних разликују највише по томе што у њима предикати истовремено и заједно важе само као одређеност два субјекта, између којих постоје односи идентитета. И сам је став идентитета један релациони суд, априорни аналитички суд, отуда закон идентитета није највиши принцип свести, јер се разноврсност реалног света не може објашњавати једино помоћу њега, него је највиши принцип свести заправо синтетички принцип опозиције супротности, јер оно што је бивствујуће, што се дакле мора мислити, што је замисливо, заправо је негативни однос: из овога највишег и последњег начела сазнања и произилазе став разлога и став противречности као међусобно несводива начела мишљења. Шопенхауер и Вунт нису дакле у праву када су законе искључења трећег и двоструке негације прогласили темељним законима мишљења.

Став разлога, према коме све што јесте, или може да се замисли, мора да има довољан разлог зашто јесте, или може да се замисли, тако како јесте, а не другачије, састоји се по својој суштини у изразу зависности последице од разлога, будући дакле да је разлог само оно из чега нужно следи последица. А то је пак могуће као однос између реалних чињеница и као однос између сазнајних чињеница, тако су разлози реални и сазнајни, који се поклапају у математичким објектима и у подручју квалитета. Осим тога, разлози су унутрашњи и спољашњи, постоји и саморазлог, међу које је Петронијевић сврстао начине односа спољњег света који постоје изван свести, дакле квалитет, квантитет, место, стање и ред. То дакако подсећа на скраћени попис Аристотелових категорија.

Петронијевић узима негацију као реалну везу утемељења разлога и последице, а сам је став разлога узет као начело релације, будући дакле да суштина става разлога и лежи у релацији. Али, став разлога је чисто формални закон мишљења, сходно датости садржаја бића, стога је нужно његово утемељење на подручју универзалног јединства, или свеобухватног бивствујућег, које очито не може да изван себе има за себе довољан разлог, јер се ништа обухватније од свеобухватног не може замислити. Ово отуда што је нужно само оно чија супротност није могућа, а када није могућа онда је она апсолутно реална. Ова апсолутна нужност односи се и на подручје појединачних јединица као саставних делова бивствујућег, јер и сваки је такав појединачни 
саставни део бивствујућег такође апсолутно нужан. Овакав однос појављује се и у мировању и кретању, где је мировање заправо првобитно стање бића, а кретање негација мировања, а из ове негативне природе кретања произилази да оно не може бити континуирано стање бића. Сад, чуди се Петронијевић, како овај тако јасан и нужан однос мировања и кретања није сазнат, јер да је сазнат, онда не би се до сада говорило о вечном кретању, апсолутној промени, вечној актуелности бивствујућег. А то што уопште у свету и постоји кретање, има свој разлог у одлуци воље, јер апсолутна нужност управља и надоле и нагоре свему бивствујућем свег замисливог, где је нужно схваћено као оно што има довољан разлог зашто јесте такво какво јесте, чему онда супротност није ни могућа. Таква нужност је или условљена или безусловна, а условљена нужност јесте првобитна форма нужног.

Како је основни, примарни облик става разлога позитивноконтрадикторни однос, у реалном однос два праквалитета, два атрибута бивствујућег, то се онда поставља и питање суштинских врста односа зависности између разлога и последице, дакле посредна и непосредна, симултана и сукцесивна, двострана и једнострана, датих према гледиштима односа, реда и веза. Петронијевић је размотрио њихове међусобне односе, како би у њима разликовао три врсте негације, просту и спољашњу, једноставну и унутрашњу, рефлексивну и унутрашњу негацију, где прва постоји између две симултано дате супротности, ова друга између односа опозиције и две супротности а ова трећа између целине и ничега.

Став разлога је опште начело сазнања, и то начело стоји у односима према другим начелима, тако и начелима сврхе, развоја и супстанције. А начело сврхе није формално начело, као став разлога, или као каузални принцип, оно је наиме садржинско начело света, стога је оно садржај става разлога као свеобухватног начела бивствујућег, с тим што у јединству са каузалним начелом сачињава опште логичко начело јер свака логичка идеја обухвата и садржај и форму бивствујућег. У подручју бивствујућег, када се у њему допусти апсолутно бивање, тражи се апсолутна супстанција, па се онда допушта и двојност у бивствујућем, дакле непроменљива и самостална супстанција и непроменљива и несамостална акциденција, што није прихватљиво, будући да је настало површном рефлексијом о искуственом привиду. Како је дакле 
појам несамосталног, апсолутно непроменљивог бића contradictio in adiecto и како је он у противречности с метафизичким аксиомом става разлога, то онда ове несрећне појмове треба заменити појмом активно променљиво, а то није апсолутна промена бића него само констелација делова бића.

Према томе, није супстанција оно последње самостално бивствујуће, него је, каже Петронијевић у завршном ставу додатка у својој дисертацији, заправо у атрибутима то последње самостално, истинско биће, срж бивствујућега, јер су атрибути они последњи истински носиоци одредбеног начела, начела негације.

Оно дакле што је овде метафизичко у логици једновремено је и логичко у метафизици, овако схваћени став разлога код Петронијевића важи како за мишљење тако и за биће, јер став разлога изражава и форму зависности садржаја мишљења и форму зависности садржаја бића у њиховим односима. Тек је тиме схватљиво зашто је Петронијевић устврдио како се не може оправдати претпоставка о постојању променљивости и несамосталности бића, зашто, затим, мора да постоји апсолутна супстанција као коначни разлог, те онда зашто је биће вечно и апсолутно. Али, став разлога и став противречности, где је овај други схваћен као садржински принцип мишљења, показују се у својој коначној сврси као међусобно несводива начела мишљења која се допуњују и прожимају, с тим да је очито како они произилазе из једног истог принципа мишљења, који је код Петронијевића дат исказом да је бивствујуће негативни однос. Отуда је логички задатак филозофије, да дедукцијом изведе сву посебност садржаја бића из овога начела, или из њему сродног начела, и та логичка дедукција бића у метафизици и јесте заправо метафизичка логика.

Метафизичка логика назначена је, премда не и проведена, и на многим местима у Принципима метафизике, посебно у поглављу о дедукцији квантитативно-квалитативне структуре бивствујућег из начела негације, како је дато у другом делу прве свеске овог списа. Заправо, код Петронијевића није нигде метафизичка логика ни проведена као систем знања о логичкој дедукцији бића и бивствујућег из врховног онтолошког начела негације, само је приказана чисто логичка дедукција квантитативно-квалитативне структуре бивствујућег из начела негације, како би се показало да, заједно са већ утврђеном стварно постојећом квантитативно-квалитативном структуром бивствујућег на основу битних чињеница непосредног искуства, стварност може бити једино таква 
каква доиста и јесте. Тако, онтолошки и логички процес дедукције оне структуре бивствујућег из непосредног искуства и начела негације и сачињава један јединствени метафизички процес, у коме је овај други део тог процеса схваћен као процес метафизичке логике. Тако постављеном дедукцијом структуре бивствујућег Петронијевић је извео безвременски и временски стадијум бивствујућег. У тој дедукцији, стварност се показала као систем душевних индивидуа и материје, дакле свесне и несвесне природе, где се последњи елементи материје, као супстрати појава спољашње несвесне природе, могу свести на монаде са минималним садржајем свести, а онда и да се душевни живот монада може објаснити на основу метафизичких начела (Petronievics 1912:254-255). То онда припада метафизици, јер њен је наравно задатак да емпиријско-индиректним разлозима докаже тачност решења проблема материје и душе. Петронијевић је дакле држао како је он показао ту тачност решења, те да је метафизичка логика заправо логика извођења дедукције метафизичког проблема односа несвесне и свесне природе, материје и душе.

Показало се међутим како је и тај процес дедукције заправо процес формалне логике, примењене у подручје метафизичке филозофије, те да тако није ни прекорачен домашај традиционалне логике у њеној примени на ствари метафизике.

\section{ЛИТЕРАТУРА}

Петронијевић, Бранислав (1990). Основи логике. Формална логика и општа методологија, Београд: Белетра

Petronievics, Branislav (1898). Der Satz vom Grunde. Eine logische Unterrsuchung. Von Branislav Petronievics, Belgrad: Königlich-serbische Staatsdruckerei

Petronievics, Branislav (1904). Prinzipien der Metaphysik, Erster Band, erste Abteilung, Heidelberg: Carl Winters Universitätsbuchhandlung

Petronievics, Branislav (1912). Prinzipien der Metaphysik, Erster Band, zweite Abteilung, Heidelberg: Carl Winters Universitätsbuchhandlung

Петронијевић, Бранислав (1986). Начела метафизике, 1-2, Београд: Бигз 
Петронијевић, Бранислав (1997). Резиме филозофских и научних радова, Београд: Завод за уџбенике и наставна средства

Mirko Aćimović

\title{
BRANISLAV PETRONIJEVIĆ'S LOGIC
}

\begin{abstract}
Summary
The transition from the science of forms of thought and methods of knowledge to the science of principles of objective logical content of being was indicated through foundations, structure and theoretical scope of formal and metaphysical logic in the philosophical system of Branislav Petronijević. Hence, the formal logic and metaphysical logic are propedeutical sciences of Petronijević's system of metaphysics which together with the theory of knowledge and logic constitute the pure philosophy in the synthesis of universal knowledge.
\end{abstract}

Key words: formal logic, metaphysical logic, metaphysics, being, negation. 